\title{
In-Service Teachers' Perception of Continuing Education Programmes in Two African Universities
}

\author{
Francis O. Olaniyi $P h D$ \\ Department of Adult Education \\ Faculty of Education \\ Adekunle Ajasin University, AkungbaAkoko, Nigeria \\ E-mail: francisolaniyi@yahoo.com \\ Dumisani R. Nzima \\ Professor \\ Department of Educational Psychology and Special Education \\ Faculty of Education \\ University of Zululand \\ Kwa Dlangezwa, Republic of South Africa
}

\begin{abstract}
The study compared the in-service teachers' perception of continuing education programmes from two universities in Africa; University of Zululand, South Africa (UZ), and Adekunle Ajasin University, Akungba-Akoko, Nigeria, (AAU). The study covers the impact, effectiveness and efficiency of UZ and AAU on in-service teachers' of continuing education programmes. The target population and sample for the study were the current teachers of continuing education programmes of these universities. The instrument tagged 'Questionnaire for Perceptions of Continuing Education Programmes by in-service Teachers' (QPCEPIT) was designed and used for data collection. The descriptive survey research design of ex-post facto was adopted for the study. I50 questionnaires were randomly used for pilot study, carried out at Ekiti State University, Ado Ekiti, Nigeria, whilst 500 questionnaires each were administered at both UZ and AAU of which 365 and 32I responses were valid and analysed respectively. Four research questions were carefully formulated to ascertain the perceptions of continuing education programmes by in-service teachers in the selected universities. Inferential statistics was used to draw conclusions and test the research questions for the study. The results of the comparative study revealed that the conclusiveness of the learning environment, the nature and quality of student support services provided, the quality and learners' perception of course modules or materials, accommodation problems and venue of the programme were the major predictors for motivation of in-service teachers of the programme. Based on the findings of the study recommendations were made on how the programme will have impact on the in-service teachers and how the universities that are running the programme will be effectively and efficiently manage the programme for the acceleration and advancement of socio-economic growth in South Africa, Nigeria, and the world at large.
\end{abstract}

Keywords: Postcoloniality; Language; Orientalism; Colonizer; Colonized; Identity; Hybridity.

\section{Introduction}

This chapter looks at the perceptions of continuing education programmes by in-service teachers from two universities in Africa: Universities of Zululand (South Africa) and Adekunle Ajasin (Nigeria) as a correlate of motivating adult learners to acquire additional qualifications when it is not possible for them to combine full time employment with regular academic programme. In past days, when there were employment opportunities, workers in Nigeria enjoyed study leave with-pay and after acquiring additional qualification they return to their work place to resume duties. Similarly in South Africa, workers prefer to proceed on academic programme on part time basis because of the fear of losing their jobs. There was a lot of employment in the past readily available for university graduates but because of economic crunch in Nigeria in the early I980s, many workers prefer to combine world of work with part-time programmes to attain additional qualifications and at the same time maintain their work. Continuing education as a branch of adult education sets out to increase access to a wider section of adult population, to enable participants combine world of work with study without losing their jobs. These sets of adult learners are of diversified experiences. This view is shared by Aderinoye (1997; Ojo (20I0); Egunyomi \& Aderinoye (200I); Hayes (2006); Christie (2008); Mestry, and Hendricks \& Bisschoff (2009)

In the world of today, knowledge has been considered as the most important factor of production and its growth is essential to propel an individual into self-sustained growth (Drucker, I994). Thus, a knowledge individual will inevitably become far more competitive than any individual, we have yet known, for the simple reason that with knowledge being 
universally accessible, there are no excuses for non-performance. Hence, there will be no poor individual; there will only be ignorant individuals (Drucker, 1994). It is with these views that the contemporary economy and society have been aptly tagged "knowledge driven economy" or "Knowledge society". Knowledge driven economy is often defined as an economy that's most important elements are the possession, control, production, and utility of knowledge and intellectual resources (UNESCO, 1996). Knowledge society, in a similar perception, is seen as a society where the value of knowledge is the primary source of economic growth and corporate profits. Hence, a knowledge society produces commodities of high knowledge value. There is over-reliance on dated sources.

As way of helping teachers to achieve additional qualifications without leaving their job, the Nigerian government, in line with the education policy documents including the Education For All (EFA), Millennium Development Goals, National Policy on Education (NPE), National Teacher Education Policy (NTEP), Vision 20-20-20, and Transformation Agenda, has acknowledged the important role of continuing professional development programmes for teachers. The National Teachers Institute was established, as a government parastatal, to accomplish government's vision of upgrading the quality of her teachers. Specifically, the vision of the institute is to produce quality, highly skilled, knowledgeable and creative teachers based on explicit performance standards through pre-service and in-service programmes, which are able to raise a generation of students who can compete globally. The institute, since its establishment, has pushed with vigour various strategies and programmes for improving the quality of teachers through continuing professional development of teachers (Aderinoye, 2007).

Besides, the National Policy on Education (NPE), the Vision 20-20-20, the Roadmap for the Education Sector and the National Teacher Education Policy (NTEP) all these recognize the role of the teachers in improving the quality of learning outcomes in Nigerian schools. According to the National Policy on Education (2007), "in recognition of the pivotal role of quality teachers in the provision of quality education at all levels, teacher education shall continue to be emphasized in all educational planning and resource development". Thus, the teacher factor is critical to any improvement in the educational system. This is the basis for the often quoted cliché that "no system of education can be above the quality of its teachers". Thus, the teacher is a critical factor in any effort that is aimed at improving the quality of education. As Torres (2000) put it "competent and dynamic teaching workforce would ultimately produce efficient and effective human resources for individual and national progress". Aderounmu(2007) also reported that research had shown that "high-quality teachers, using proven teaching methodologies, produced high achieving students..."

Besides government's parastatals set up to improve teachers' quality, tertiary institutions in Nigeria have also instituted different continuing education programmes aimed at improving teachers' quality. One of such institutions is Adekunle Ajasin University in Ondo State of Nigeria. The institution's continuing education programme is one which in-service teachers, especially in the South-West region of the country hold in high esteem through patronage. Higher institutions in other regions in Africa have equally established various continuing education programmes meant to upgrade the knowledge and skills of inservice teachers in terms of acquiring additional qualification. One of such institution is University of Zululand in Kwa Dlangezwa, Republic of South Africa. The University has a high enrolment rate of in-service teachers in its part time programme in the faculty of education. Perhaps, the reason why these teachers have embraced a part time education programme is simply due to the fact that continuing education, as a branch of adult education, sets out to increase access to a wider section of adult population, to enable participants combine world of work with study without losing their job. According to Abdullahi (I997:74) "Continuing education programmes have created more successes to university education and contributed immensely to teachers' professional development”?

Furthermore, Hayes (2006) submitted that recent university graduates who have been recently employed may want to make a career change and need to gain knowledge of a different profession or industry, or may be seeking a promotion for which they need a different set of skills; there is no other means than to engage in continuing education programme.This study is, therefore, designed to find out how the in-service teachers enrolled in the continuing education programmes of these institutions (Adekunle Ajasin University (AAU), located in Akungba-Akoko, Ondo State, Nigeria, University of Ado-Ekiti (UNAD), Ekiti State, Nigeria and University of Zululand (UZ), KwaDlangezwa, KZN, South Africa) perceived the programme. The choices of these institutions become justifiable due to the fact that the Universities exist in an environment where the value for university education is already appreciated by the members of the community and the entire countries at large. In addition, the institutions are public universities that are pursuing continuing education programmes right from the period of their establishment for the professional development of teachers at large.

\section{Objectives of the study}

The specific aim of the study is to investigate the perceptions of continuing education programmes by in-service teachers from two universities in Africa: Universities of Zululand (South Africa) and Adekunle Ajasin (Nigeria). The specific objectives of the study are:

- To examine the perceptions, role and impact of continuing education programmes on how in-service teachers will professionally develop themselves; and 
- To examine if continuing education programmes is the only source or means by which universities could assist inservice teachers to be professionally developed.

\section{Scope of the Study}

The scope of the study is limited to three institutions, namely; Adekunle Ajasin University (AAU), located in Akungba-Akoko, Ondo State, Nigeria, University of Ado-Ekiti (UNAD) now Ekiti State University, Ekiti State, Nigeria, and University of Zululand (UZ), Kwa Dlangezwa, South Africa). Participants included in-service teachers who have enrolled and pursuing B. Ed/B.A (Ed.)/B. Sc. (Ed) degree programmes in each institution's Faculty of Education through continuing education programme.

\section{Research questions}

- What are the perceptions of continuing education programmes by in-service teachers in professional development in South Africa and Nigeria?

- Do learning modalities of continuing education programmes of University of Zululand and Adekunle Ajasin University have desirable effects on learners' knowledge utilisations?

- What are the problems confronting continuing education programmes of UZ and AAU?

\section{Literature Review}

\section{I Concept of continuing education}

Omolewa (2000) posits that continuing education is re-education, training and retraining opportunities that are made available to out-of-school youth and adults, employed and unemployed, to enable them cope with new challenges of life. From his idea, one can say that continuing education provides learning opportunities that can be taken up after the cessation of full-time compulsory schooling. It is a kind of programme that is available to persons of any age and could be provided on part time basis. Egunyomi, (1999) and Jegede (2010) further stressed that the quality of a person's life would be affected by his/her ability to acquire new knowledge throughout life and to use this knowledge to solve problems and make decisions.

The Federal Government of Nigeria upholds the existence of continuing education. The National Policy on Education (NPE) (2004) lists continuing education among the components of adult and non-formal education. Section 7 of the document states that adult and non-formal education consists of functional literacy, remedial, continuing, vocational, aesthetic, cultural and civic education for youths and adults outside the formal school system.

In the same policy document, the objectives of adult and continuing education should be:

- To provide functional literacy education for adults who have never had the advantage of any formal education.

- To provide functional and remedial education for those young people who prematurely dropped out of the formal school system.

- To provide education for different categories of completers of the formal education system in order to improve their basic knowledge and skills.

- To provide in-service on-the-job, vocational and professional training for different categories of workers and professionals, in order to improve their skills.

- To give the adult citizens of the country necessary aesthetic, cultural and civic education for public enlightenment. It is observed from this policy that continuing education should be an agent of national development and establishment of continuing education centres which must call for effective planning and execution. Teachers could update and acquire new skills and knowledge of subjects to disseminate the contents to the learners through effective professional development programmes, and thereby enhance student learning.

The whole idea is that when adults continue their education, they are more likely to discover a job which matches their passion and talents. These golden opportunities allow someone to "test the water" before jumping into a new career. The benefit of adult education is learning about perspective career fields which may lead to a dream job. However, several important assumptions about adult learners are worth emphasizing. These assumptions are paramount and could guide many aspects of adult learning situations since learning itself is a process of acquisition of knowledge; and knowledge could not be acquired without curriculum which should be reformed to seek improvement in quality by increasing the ability of teachers to deliver the curriculum, reducing diversity or derivation from standards of excellence (McGinn, 1998).

\subsection{South African Education before 1994}

History has it that the South Africa education system was initially divided into I5 departments of education. These were the Department of National Education (DNE); the Departments for Education and Culture (DEC) for the Whites, Indians and Coloureds; the Department of Education and Training (DET) responsible for African education in urban areas, six Department of Education and Culture for independent state. Consequent upon this division, the Department of National Education (DNE) 
was inaugurated due to the National Policy for General Education Affairs Act 76 of I984. This policy was responsible essentially for the formation of education policy for all education departments. Coupled with this is the fact that the DNE developed national policies and standards for certification and remuneration (Behr, 1984). These policies on education matters were judiciously expressed in the South African National Education Policy (SANEP) publications which were released to the various departments of education. These publications equally expressed the general policy regarding the evaluation of teachers in South African schools. This criterion was used for the evaluation on probation and for promotion and for merit awards (SANEP-NATED, 1987; Department of Education and Training; (Jarvis, I983). The DNE was responsible for "general affairs" as stated in the Republic of South Africa Constitution Act I IO of I983. It is worthy of note to mention that each of the other I4 departments of education regulated their own affairs specific to each population group in the Republic of South Africa. The house of assembly regulated education for whites within the parliament. Their education was further divided into four provincial departments, that is, Cape, Natal, Orange Free State and Transvaal. Meanwhile, the House of Delegates (HOD) was responsible for Indian education and the House of Representative (HOR) was in charge of education for coloureds. Both houses were represented in the South African Parliament. However, the DET which was in charge of African education, in urban areas was not represented by a house in parliament. It was an accident of history that those Africans who were not under the jurisdiction of the DET were placed under six major departments of education in their self-governing territories of KwaZulu, Kangwane, Gazankulu, KwaNdebele, QwaQwa and Lebowa. The aforementioned departments were responsible for their own education system and had 'autonomy' from the South African government. The independent states of Bophuthatswana, Transkei, Ciskei and Venda were also responsible for their own education.

These departments were spread rapidly over the four provinces of South Africa. These are: Cape Town, Natal, Orange Free State and Transval. In Natal alone, there were five departments of education, namely: DET, HOD, HOR, KDEC and NED. Since the 1994 elections, all I5 departments of education have merged into one National Department of Education which was further divided into nine provincial departments of education. These provincial departments are Eastern Cape, Guateng, Kwa Zulu Natal, Mpumalanga, Northern Cape, Northern Province, North West, Orange Free State and Western Cape. It should be noted that a new Kwa Zulu Natal Department of Education was established after the I994 elections. Nevertheless, the formerly segregated departments of education continued to operate while integration was in progress. These various departments operate and applied different evaluation procedures.

\subsection{Concept of adult education}

Generally, the concept of adult education in academic circles throughout the world today varies from one school of thought to another. The term adult education is perhaps one of the most difficult to define. Adult education, according to Omolewa (I98I) and Ahmed (I999), is sometimes defined as the education provided for all men and women who are aged 2I and above. This is a biological definition based on the assumption that an adult is one who is aged 2I and above. This definition forgets that in some countries, men aged 18 are considered as adults for purposes of election and other responsibilities. Besides, it fails to recognise that men aged 16 could be as physically and mentally mature as men aged 35 and even 40 . This shows that adult education cannot be limited to a particular age since people recognized as adult vary from one society to another.

UNESCO also adopts the age criterion but reduces the age limit when it states that the term adult education covers all organised educational activities provided for people who are not in the regular school and university system and who are generally fifteen or older (Omolewa, I98I). Therefore from the view of UNESCO definition on age criterion, any education given to adult outside the formal school system after I5 years of age is adult education. The Federal Government of Nigeria (FGN) was aware of the age limitation when it adopted the programme-based definition. The Federal Government of Nigeria in 2000 stated that adult and non-formal education may be aimed at young people who legally have not attained adult's status, but for whom there is no further provision within the school system (Ezimah, 2004). The global concept of adult education has introduced major changes to educational practice. The concept is revolutionary in nature and it represents a switch of emphasis from teaching to learning and denying the validity or the assertion of the notion that learning is confined to a certain age that takes place only in schools.

Adult education may be viewed from a functional perspective, for example, it may be conceived as vocational or agricultural or industrial education, the education which encourages the use of $3 \mathrm{Hs}$ (the Head, Hand and Heart) (Okediran, 200I). To some, therefore, adult education is often seen as the training of adults in science and technology, crafts and sometimes in humanities. The idea is that adult education would assist adults in the lack of the application of knowledge and skills to existing resources and in the promotion of civic awareness through political discussions.

The consensus on the ultimate aim of adult education is to help all and sundry to make the best of life by providing a means of:

- Remedying earlier education defects through its widening access strategy,

- Acquiring new skills,

- Upgrading oneself vocationally,

- Increasing one's understanding of the world, and 
- Personality development.

The above contextual and conceptual analyses, therefore, show that adult education is a comprehensive form of education for adults covering all aspects and categories of adults, all categories of education and using a variety of methods.

\subsection{In-Service education}

In-service education is regarded as a kind of programme of instruction or training provided by an agency or institution for its employees. The programme is held in the institution or agency and it is intended to increase the skills and competence of the employees in a specific area. In- service education may be a part of any programme of staff development and usually organised on a part-time basis (week end) or on a specific period, long vacations that is convenient for the learners. In the same vein, staff development is paramount for every organisation or establishment to improve work morale and efficiency of a worker.

If people working in a particular profession are given in-service training, they attend special courses to improve their skills or to learn about new developments in their field. However, it is obvious that every staff member must be adequately developed by the employer or personally by the worker him/herself.

\subsubsection{Professional development}

Many people make a decision about jobs and careers after leaving high school or college, some based on clear goals and others on need. However, there are many varied and often uncontrollable reasons why these initial occupations do not last. This may lead to several reasons why continuing education must be considered as a positive investment for achieving success in a chosen occupation. Job instability is one of many reasons why everyone needs to pursue continuing education irrespective of one's academic attainment or vocation in any field. Additional education helps remain current within a carrier field. No doubt, changing jobs several times in one's life is quite inevitable in human endeavour. More importantly, career investment may prompt an individual to enroll in continuing education programme. A job is the most suitable asset anybody could have in his or her life time. This implies that many will not hesitate to invest in a career that will enable them realise this goal (Oladipupo $\&$ Adetoro, 2008).

It is obvious from this definition that professional development is a "process" which is ongoing and not an end in itself. It is a clear assumption that a number of steps needs to be followed for its cause to be recognized and perform what it is expected to yield in term of execution, performance, and result. The outcome of professional development is improvement of performance and meeting performance expectations.

\section{Research Methodology}

\section{I Research design}

The descriptive survey research design of ex-post facto was adopted for this study (Hesse-Biber, 20I0).

\subsection{Population for the study}

The population for the study was the current students of the continuing education programmes of these Universities.

Tables I and 2 below show the distribution and administration of questionnaires at both universities.

\begin{tabular}{lcc}
\hline \multicolumn{3}{l}{ Table I: Administration of Questionnaires at University of Zululand, South Africa } \\
\hline Type of programme & $\begin{array}{l}\text { Number of questionnaires } \\
\text { administered }\end{array}$ & Number of valid questionnaires \\
\hline B. Ed. (Hons.) & 20 & 16 \\
\hline PGCE & 20 & 14 \\
\hline NPDE & 460 & 322 \\
\hline TOTAL & 500 & 365 \\
\hline
\end{tabular}

Source: Researcher’s Field Survey, 2012

Table 2: Administration of Questionnaires at AdekunleAjasin University, Nigeria

\begin{tabular}{lll}
\hline Year/level of study & Number of questionnaires administered & Number of valid questionnaires \\
\hline I00 level/ ${ }^{\text {st }}$ Year & I00 & 67 \\
\hline 200 level $/ 2^{\text {nd }}$ Year & I00 & $6 \mathrm{I}$ \\
\hline 300 level $/ 3^{\text {rd }}$ Year & I00 & 59 \\
\hline 400 level $/ 4^{\text {th }}$ Year & I00 & 65 \\
\hline 500 level $/ 5^{\text {th }}$ Year & I00 & 69 \\
\hline TOTAL & 500 & 321 \\
\hline
\end{tabular}

Source: Researcher's Field Survey, 2012. 


\subsection{Sample}

Samples of 1000 questionnaires were administered at both AAU and UZ. There were only few students offering B Ed Hons and PGCE programmes at UZ but there were more than enough students for the National Professional Diploma in Education programme. The selection of students at AAU spanned all the levels of B.Ed Hons.

Instrument

A self-prepared questionnaire was a key tool used for this study.Likert-type attitudinal rating scale was adopted. Five (5) answers were given out of which the respondents were expected to pick one, i.e. SA $=$ Strongly Agree ( 5 points), A = Agree ( 4 points), UD $=$ Undecided ( 3 points), $\mathrm{D}=$ Disagree ( 2 points $)$ and $\mathrm{SD}=$ Strongly Disagree ( $\mathrm{I}$ point).

\section{Data Analysis}

The research questions were tested with the use of descriptive statistics.

\section{Result and Discussion}

Research questions

Research Question I: What are the perceptions of continuing education programmes by in-service teachers in professional development in South Africa and Nigeria?

Table 3: The lecture mode you enjoy most

\begin{tabular}{|c|c|c|c|c|}
\hline \multicolumn{2}{|c|}{ The lecture mode you enjoy most } & \multirow{2}{*}{$\frac{\mathrm{UZ}}{\mathrm{I} 2 \mathrm{I}}$} & \multirow{2}{*}{$\begin{array}{l}\text { AAU } \\
86\end{array}$} & \multirow{2}{*}{$\frac{\text { Total }}{207}$} \\
\hline Discussion & Count & & & \\
\hline method & \% within Institution & $34.1 \%$ & $28.6 \%$ & $31.6 \%$ \\
\hline \multirow{2}{*}{$\begin{array}{l}\text { Lecture } \\
\text { method }\end{array}$} & Count & 90 & $\mathrm{I} 23$ & 213 \\
\hline & $\%$ within Institution & $25.4 \%$ & $40.9 \%$ & $32.5 \%$ \\
\hline \multirow{2}{*}{$\begin{array}{l}\text { Group } \\
\text { method }\end{array}$} & Count & 55 & 17 & 72 \\
\hline & \% within Institution & $15.5 \%$ & $5.6 \%$ & $11.0 \%$ \\
\hline \multirow{2}{*}{$\begin{array}{l}\text { Face-to-face } \\
\text { lecture } \\
\text { method }\end{array}$} & Count & 88 & 73 & I6I \\
\hline & \% within Institution & $24.8 \%$ & $24.3 \%$ & $24.5 \%$ \\
\hline \multirow[t]{2}{*}{ Other } & Count & $\mathrm{I}$ & 2 & 3 \\
\hline & \% within Institution & $.3 \%$ & $.7 \%$ & $.5 \%$ \\
\hline \multirow[t]{2}{*}{ Total } & Count & 355 & 301 & 656 \\
\hline & \% within Institution & $100.0 \%$ & $100.0 \%$ & $100.0 \%$ \\
\hline \multicolumn{2}{|c|}{ The lecture mode you enjoy most } & UZ & AAU & Total \\
\hline \multirow{2}{*}{$\begin{array}{l}\text { Discussion } \\
\text { method }\end{array}$} & Count & $\mathrm{I} 2 \mathrm{I}$ & 86 & 207 \\
\hline & \% within Institution & $34.1 \%$ & $28.6 \%$ & $31.6 \%$ \\
\hline \multirow{2}{*}{$\begin{array}{l}\text { Lecture } \\
\text { method }\end{array}$} & Count & 90 & $\mathrm{I} 23$ & 213 \\
\hline & \% within Institution & $25.4 \%$ & $40.9 \%$ & $32.5 \%$ \\
\hline \multirow{2}{*}{$\begin{array}{l}\text { Group } \\
\text { method }\end{array}$} & Count & 55 & 17 & 72 \\
\hline & \% within Institution & $15.5 \%$ & $5.6 \%$ & $11.0 \%$ \\
\hline \multirow{2}{*}{$\begin{array}{l}\text { Face-to-face } \\
\text { lecture } \\
\text { method }\end{array}$} & Count & 88 & 73 & I6I \\
\hline & $\%$ within Institution & $24.8 \%$ & $24.3 \%$ & $24.5 \%$ \\
\hline \multirow[t]{2}{*}{ Other } & Count & $\mathrm{I}$ & 2 & 3 \\
\hline & \% within Institution & $.3 \%$ & $.7 \%$ & $.5 \%$ \\
\hline \multirow[t]{2}{*}{ Total } & Count & 355 & 301 & 656 \\
\hline & \% within Institution & $100.0 \%$ & $100.0 \%$ & $100.0 \%$ \\
\hline
\end{tabular}

From the Table above it could be seen that the lecture mode enjoyed most by the respondents at UZ is discussion method and it accounts for 34.1\% while in AAU, the lecture mode they enjoyed most is lecture method and it accounts for $40.9 \%$. It is evident that there are differences in the way and manner the two students from the sampled Universities perceived lecture deliveries. UZ students preferred discussion method whilst AAU students preferred lecture method. There were 
similarities in the face-to-face lecture method from the two Universities because there was no significance difference in the perception of the respondents in this regard.

Research Question 2: Do learning modalities of continuing education programmes of University of Zululand and Adekunle Ajasin University have desirable effects on learners' knowledge utilisations?

Table 4: Do you enjoy the mode of delivery being used?

\begin{tabular}{lrr}
\hline & UZ & \multicolumn{1}{c}{ AAU } \\
\hline Yes & $89.0 \%$ & $78.7 \%$ \\
\hline No & II.0\% & $21.3 \%$ \\
\hline Total & $100.0 \%$ & $100.0 \%$ \\
\hline
\end{tabular}

From the table above $89 \%$ of the respondents in UZ enjoyed the mode of delivery being used as a continuing education learner, while II\% did not enjoy the mode of delivery being used. On the other hand, $78.7 \%$ enjoyed the mode of delivery in AAU while 21.3\% did not. It is also evident from Table 4 that all the methods of teaching were acceptable to the students except others which were not clearly defined. It could be concluded that all the methods used for the delivery of all lectures were acceptable to the students as shown in Table 50 above.

Research Question 3: What are the problems confronting continuing education programmes of UZ and AAU?

$44.4 \%$ of the respondents agree or strongly agree that hostel accommodation facilities are adequate, while the remaining $55.8 \%$ said otherwise. This shows that hostel accommodation is not adequate; therefore, it is one of the problems confronting continuing education programmes of AAU in Nigeria. $61.9 \%$ of the respondents agree or strongly agree that permanent hostel for continuing education students recommended.

\section{Conclusion}

No doubt, the study has revealed the perceptions and important role(s) that continuing education could play in assisting inservice teachers in particular to develop themselves and acquire more knowledge, skills and obtain additional qualification to upgrade their academic attainment. The analyses of the data testing the research questions revealed that the modes of lecture deliveries in the two universities are not the same. On effectiveness of the programme, hypothesis two revealed that effectiveness of continuing education or sandwich programme could be affected by the university or institution attended by the learners, this shows that institution has a significant effect on the effectiveness of the programme. The efficiency of the programme has to do with the organisers and coordinators of the programme at various levels. This is revealed in hypothesis three that efficiency of the programme could also be attributed to the university or institution attended by the learners. Tables 39 and 40 showed that there is a difference in the effectiveness and efficiency of continuing education or sandwich programme in UZ and AAU.

Results of the study further showed that learners generally hold a positive perception and attitudes to continuing education programme, compared to full time programme because of their being in full time employment. Studies have also determined that students taking continuing education programme, sandwich programme, distance learning courses perform as well as students taking courses via traditional methods (Gagne \& Shepherd, 200I). In the present society, all over the world, teachers are primarily concerned with things that will give them either immediate result or practical value (Siaciwena, 20II). Examples of such things that are real in their lives are: promotion in work place, to level up with peer group, development and self-actualisation, able to contribute their quota to social, economic and political matters in their community at large (Anyanwu, Omole \& Akintayo, 1988).

If there is going to be satisfactory learning experience for learners of continuing education programme in the university, pragmatic management strategies that are focused on adults or mature learners' needs are desirable, and should be able to pay honorarium as at when due. The payments of honorarium to lecturers at UZ are paid promptly without stress. The lecturers of AAU, revealed that the lecturers were not paid when due, and the honorarium paid to them is not commensurate with what other universities pay to their lecturers. Looking at sandwich programmes at AAU, there is still a lot to be done for the programme, if it is to be compared with what is obtainable in advanced countries of the world, for example, USA, Canada, Britain, and also with what obtains at UZ, and at the same time to be regarded as a complement to the efforts of the conventional universities in the provision of manpower supply and educational development in Nigeria. 


\section{Recommendation}

In the light of the findings from this study, the following recommendations are made, viz:

- The study revealed that continuing education is important for the professional development of teachers irrespective of their gender, status, religion and level of academic attainment. It is highly recommended that teachers should be encouraged by sponsoring them for professional development from time to time;

- Teachers are expected to play vital roles in economic, social and political developments of a Nation hence there must be dare need for professional development;

- Apart from the experience of learners of AAU sandwich programme, the management of this university should set up a committee to look into the problems or request of sandwich students, and make necessary recommendations for the improvement of the programme. Also, effort should be put in place for the learners to have their lectures at the main campus of the university. Accommodation facilities during contact session should be looked into, for the convenience of the learners. Other things are the students support services, recruitment of qualified lecturers for the institute of education, the infrastructures of the study centres and the quality of the course materials;

- There is also a need for commensurable reward in term of honorarium for the lecturers. This will enable them to be more committed to teaching and research during contact session for the learners. Increase in the teaching practice allowance for the lecturers is also recommended because practicing schools for the learners are spread all over long distances outside the university community.

- The Students' Affairs Department (SAD) of the universities should look into the welfare of the continuing education learners in line with what operates with the regular students;

- To organise a continuing education programme, the organisers, that is, the university, need the support of the community for the use of facilities and sponsorship of indigent workers who should be given the opportunity of higher education in order to merge gown and town relationship. Hence organisers should always seek the assistance of the community and also make their services available to the community when they are needed;

- Information and communication technology have changed the trend of non-formal education and the delivery of higher education all over the world; from virtually classroom to cyber campus, information technologies should continue to assist teaching and learning especially in sandwich or continuing education programmes;

- For the acceleration and advancement of socio-economic growth in South Africa and Nigeria, there should be greater and increased access to university education to acquire B.Ed degree qualification and thereafter professional development to build their capacity;

- In South Africa, the Department of Education (DoE) need to reinforce the supervision of continuing education programme to ensure quality and adequate turn out of graduates in Adult Basic Education and Training (ABET). From the Nigeria perspective, sandwich or part time programmes need to be supervised by Ministries of Education and the National Universities Commission (NUC) so that abuses to such programmes would be minimised; and

- Government and non-governmental agencies should invest in the professional development of teachers in order to boost their morale. Government and research institutions are enjoined to promote operational researches on continuing education programmes and workers education in general.

\section{References}

Abdullahi, J. (1997). Strategic manpower development in Nigeria: New challenges and directions. Education and Society, I7(3), I7-23.

Aderinoye, R. (2007). Nigeria non-formal education-Education for all global monitoring report. Paris.

Aderinoye, R. A. (1997). Literacy education in Nigeria. Ibadan: University Press Ltd.

Aderounmu, W. (2007). Impact of sandwich programme on educational development of Nigeria. In An address delivered ar LANRAD continuing education center.

Ahmed, M. (1999). Literacy and non-formal education: Overlap and divergence. In D. A. Wagner, R. L. Venezky, \& B. V. Street (Eds.), Literacy: An international handbook. New York: Westview Press.

Anyanwu, C., Omole, M., Lanre, \& Akintayo, M. (1988). Concept and practice of continuing education. In Akinpelu, Okedara \&Omolewa (Eds.) Language and Adult Education. Ibadan: University Press Ltd.

Behr, A. (1984). New perspective in South Afrian education (2nd ed.). Pretoria.

Christie, P. (2008). Opening the door of leaming: Changing schools in South Africa. Johannesburg: Heinemann.

Drucker, P. (1994). Knowledge, work and society: The social transformation of this country. Retrieved from http://www.ksg.harvard.edu/ifactory/ksgpress/www/ksgnew/transcripts/drucklec.html

Egunyomi, D. A., \& Aderinoye, R. A. (200I). Open-learning system for development:The Nigerian experience. In J. T. Okedara, C. N. Anyanwu, \& M. A. Lanre Omole (Eds.), Rethinking Adult and Non-Formal Education. Ibadan: Stirling-Horden (Nig) Ltd. 
Egunyomi, D. (1999). Principles and practice of continuing education in Nigeria. Ibadan: Gabesther Educational Publisher.

Ezimah, M. O. (2004). Knowing adult education: Its nature, scope and processes. Owerri: Springfield Publishers Ltd.

Gagne, M., \& Shepherd, M. (200I). A comparism between a distance and a traditional graduate accounting class. T.H.E Journal International Review of Research in Open and Distance Learning, 28(9), 4. Retrieved from http://www.thejournal.com/magazine/vault/A3433.cfm

Hayes, A. (2006). Teaching adults. London: Ashford Colour Press Ltd.

Henderson, E. S. (I98I). The evaluation of in-service teacher training. London: Croom Helm.

Jarvis, P. (1983). Adult and continuing education: Theory and practice (Ist Editio.). London: Routledge.

Jegede, O. (2010). Taking the distance out of higher education in 2Ist century Nigeria. In Convocation ceremony and IOth anniversary of the Federal Polytechnic, Oko, Anambra State held on friday, 28th. Oko: Unpublished.

Ojo, R. (2010). Concepts in adult education. In S. Jegede (Ed.), Adult ducation series, Vol I. Lagos: Editext Publisher Ltd.

Omolewa, M. (2000). The language of literacy. Adult Education and Development, (55), 22I-228.

Omolewa, M. (198I). Adult education practice in Nigeria. Ibadan: Evans Brothers Publishers Limited.

Okediran, A. (200I). Philisophical issues in language for adult and non-formal education in philosophical foundation of adult and non-formal education. Essays in Honour of Professor Emeritus Jones Adelayo Akanbi Akinpelu.

Ono, Y., \& Ferreira, J. (2010). Acase study of continuing teacher professional development through lesson study in South Africa. South African Joumal of Education, 30, 59-61.

Siaciwena, R. (20I I). Open and distance learning in Southern African Development Community (SADC). In Regional Open and Distance Learning Awareness Workshop. Johannesburg, South Africa.

Torres, R.-M. (2000). Lifelong learning in the North, education for all in the South. In M.-A. Carolyn (Ed.), Lifelong learning perpective (pp. 3-I2). Hamburg: UNESCO Institute for Education.

UNESCO (1996). Learning: The treasure within. Paris: UNESCO.

\section{Copyrights}

Copyright for this article is retained by the author(s), with first publication rights granted to the journal. This is an open-access article distributed under the terms and conditions of the Creative Commons Attribution license (http://creativecommons.org/licenses/by/4.0/). 